\title{
Nutritional factors affecting the fatty acid composition of bovine milk
}

\author{
BY R. J. MANSBRIDGE AND J. S. BLAKE \\ ADAS Bridgets Dairy Research Centre, Martyr Worthy, Winchester SO21 IAP
}

\begin{abstract}
The predominant fatty acids in milk are the long-chain fatty acids myristic, palmitic and stearic. These saturated fatty acids account for $75 \%$ of the total fatty acids, with a further $21 \%$ occurring as monounsaturated fatty acids of which the most prevalent is oleic acid. Only $4 \mathrm{~g} / 100 \mathrm{~g}$ of the milk fatty acids are polyunsaturated, occurring mainly as linoleic and linolenic acids. All milk fatty acids are derived, almost equally, from either de novo synthesis or directly from preformed fatty acids in the diet. There are four main dietary sources of fatty acids: forages, oilseeds, fish oil and fat supplements. The digestive tract exerts a profound influence on the fate of dietary fatty acids. The short-chain saturated free fatty acids are absorbed through the walls of the rumen or abomasum into the bloodstream. The medium- and longer-chain saturated fatty acids pass into the small intestine, diffuse across the membrane wall where they are incorporated into lipoproteins and enter the bloodstream via the lymphatic system. The majority of unsaturated fatty acids are extensively hydrogenated in the rumen. However, recent work has shown that the levels of certain saturated fatty acids can be reduced and the levels of oleic, linoleic and linolenic fatty acids increased by feeding oilseeds rich in mono- or polyunsaturated fatty acids. In addition, work reported here has confirmed that eicosapentaenoic and docosahexaenoic acids can be transferred to milk when a diet containing fish oil is fed, but the transfer efficiencies are low.
\end{abstract}

Fatty acids: Milk

Following the deregulation of the UK milk market in November 1994, farmers are beginning to recognize that they can no longer regard milk as a simple product, with quality and availability which vary depending on season, calving pattern or weather. Instead milk buyers, sensitive to the needs of the consumer, require milk of different qualities to meet various market requirements and opportunities. Developments within the market are being fuelled both by the need for new, novel, and better 'quality' milk products and by increasing consumer awareness of the interaction between health and diet.

Milk is one of the most naturally produced ingredients of the 'balanced plate'. However, despite liquid milk being $96 \%$ fat free, fat content is high when expressed as a proportion of the DM, and the fat is predominately saturated. This level of saturation has two disadvantages for manufacturers of dairy products; butter will not spread from the fridge and the report of the Committee on Medical Aspects of Food Policy (COMA) Nutritional Aspects of Cardiovascular Disease (Department of Health, 1994) advises a reduction in saturated fatty acid intake.

This report made a number of recommendations on fat and fatty acid intake. For the dairy industry the most important recommendations were those to reduce both the total fat in the diet (by $12.5 \%$ ), and the intake of saturated fat (from 16 to $10 \%$ of total dietary energy). Currently milk and milk products are major sources of fat in UK diets, accounting for up to $30 \%$ of total fat, and $40 \%$ of the saturated fat intake (Table 1). In addition, COMA recommended that intake of trans fatty acids should not increase and that consideration should be given to ways of reducing the amount in the diet. Milk and 
Table 1. Contribution of food groups to daily intakes of fat and fatty acids by adults (Adapted from British Nutrition Foundation, 1992)

\begin{tabular}{|c|c|c|c|c|c|c|}
\hline \multirow[b]{4}{*}{ Food group } & \multicolumn{6}{|c|}{ Average daily intake ( $\%$ of total intake) } \\
\hline & \multirow[b]{3}{*}{ Total fat } & \multicolumn{5}{|c|}{ Fatty acids } \\
\hline & & \multirow[b]{2}{*}{ Saturated } & \multirow[b]{2}{*}{ Trans } & \multirow[b]{2}{*}{ MUFA } & \multicolumn{2}{|c|}{ PUFA } \\
\hline & & & & & $n-6$ & $n-3$ \\
\hline Milk and milk products & 15 & 23 & 10 & 12 & 2 & 6 \\
\hline Fat spreads & 16 & 17 & 30 & 11 & 20 & 15 \\
\hline Meat and meat products & 24 & 23 & 18 & 31 & 17 & 19 \\
\hline Fish and fish dishes & 3 & 2 & 1 & 3 & 4 & 14 \\
\hline Cereal products & 19 & 18 & 27 & 18 & 22 & 17 \\
\hline Vegetables* & 11 & 6 & 6 & 12 & 24 & 22 \\
\hline
\end{tabular}

MUFA, monounsaturated fatty acids; PUFA, polyunsaturated fatty acids.

* Includes roasted and fried.

milk products account for $40 \%$ of the current daily intake of $4.8 \mathrm{~g}$ trans fatty acids/d (British Nutrition Foundation, 1992). The COMA report further recommended a twofold increase in the intake of polyunsaturated fatty acids (PUFA) from very-long-chain $n-3$ series PUFA, but no increase in the intake of $n-6$ series PUFA. Milk and milk products have an $n-6: n-3$ ratio of $2: 1$, and they currently contribute only $6 \%$ of the average daily intake of $n$-3 PUFA (British Nutrition Foundation, 1992). The decline in consumption of whole milk and dairy products which has been reported (Milk Marketing Board, 1994) is consistent with and reflects current medical advice to improve public health.

The present paper will review the nutritional factors which influence the fatty acid content of milk fat, report on the extent to which the fatty acid composition of milk fat can be manipulated by diet and speculate on further modifications to the type and level of fatty acids in milk fat which can be achieved through dietary manipulation.

\section{FATTY ACID COMPOSITION AND SYNTHESIS OF MILK FAT}

Typically, milk produced from cows fed on a diet based on grass silage contains approximately $40 \mathrm{~g}$ fat $/ \mathrm{l}$, of which up to $97 \%$ is in the form of triacylglycerol, and the remainder as monoacylglycerol and free fatty acids. Although the fatty acid content of milk is one of the most complex found in nature, with more than 500 different fatty acids identified (Hermansen, 1995), there are usually only considerable amounts of twelve to fifteen of these in any single fat. The predominant fatty acids in milk are the long-chain fatty acids (LCFA) myristic (14:0), palmitic (16:0) and stearic (18:0). These saturated fatty acids (SFA) account for $75 \mathrm{~g} / 100 \mathrm{~g}$ total fatty acids, with a further $21 \mathrm{~g} / 100 \mathrm{~g}$ occurring as monounsaturated fatty acids (MUFA) of which the most prevalent is oleic acid (18:1). Only $4 \mathrm{~g} / 100 \mathrm{~g}$ milk fatty acids are PUFA occurring mainly as linoleic $(18: 2)$ and linolenic (18:3) acids.

Milk fat is manufactured in the bovine mammary gland from glycerol and free fatty acids. The fatty acids are derived, almost equally, from either de novo synthesis from circulating acetate (C2) and $\beta$-hydroxybutyrate (C4) or directly from preformed fatty acids in blood lipoproteins. De novo synthesis in the mammary gland produces the majority of the saturated fatty acids from C4 to C14 and half the palmitic acid (16:0). 
Table 2. Transport of lipids in bovine blood (Adapted from British Nutrition Foundation, 1992)

\begin{tabular}{|c|c|c|c|c|c|c|c|}
\hline \multirow[b]{2}{*}{ Name } & \multirow{2}{*}{$\begin{array}{l}\text { Proportion of } \\
\text { blood lipids } \\
(\%)\end{array}$} & \multirow[b]{2}{*}{ Diameter (nm) } & \multirow[b]{2}{*}{ Density } & \multicolumn{4}{|c|}{ Components (\%) } \\
\hline & & & & Protein & Triacylglycerol & Cholesterol & Phospholipid \\
\hline Chylomicrons & Very low & $>70$ & Very low & 2 & 83 & 8 & 7 \\
\hline VLDL & 2 & $30-90$ & Low & 7 & 50 & 22 & 20 \\
\hline LDL & 6 & 20 & Average & 20 & 10 & 48 & 22 \\
\hline HDL & 92 & 10 & High & 50 & 8 & 20 & 22 \\
\hline
\end{tabular}

The fatty acids within the plasma lipoproteins are derived largely from digestion and absorption of dietary fat. The amounts derived from adipose tissue are variable, with the proportion changing depending on milk yield, stage of lactation and many other factors (Palmquist \& Mattos, 1978; Grummer, 1991). Under normal conditions the major preformed fatty acids in the blood of ruminants are 16:0, 18:0 and 18:1 (Duncan \& Garton, 1963). Most preformed fatty acids are delivered to the mammary gland by LDL and VLDL or chylomicrons which contain approximately $10-15,60$ or $85 \%$ triacylglycerol respectively (Table 2). Although HDL account for approximately $90 \%$ of blood lipids, they consist largely of phospholipids, cholesterol and cholesterol esters and have a very low triacylglycerol content (Christie, 1981). PUFA are not evenly distributed in the various plasma lipoprotein fractions, but tend to be concentrated in the phospholipid and cholesterol esters of the HDL (Dryden et al. 1971). Uptake of fatty acids into the mammary gland from HDL is poor (Brumby et al. 1972) and this may explain the low levels of PUFA in milk.

During the passage into the mammary gland, triacylglycerol is largely or completely hydrolysed by a lipoprotein lipase ( $E C$ 3.1.1.34). There is little further modification of preformed fatty acids within the mammary gland except for extensive desaturation of medium- and long-chain SFA, particularly 18:0 (Bickerstaffe \& Annison, 1968). For example, Storry (1981) reported that increased intake of 14:0, 16:0 and 18:0 led to increases in the corresponding cis-MUFA in milk.

\section{THE EFFECT OF DIET ON THE SUPPLY OF FATTY ACIDS}

Fatty acids present in milk fat are derived either directly or indirectly from the diet. There are four main sources of fatty acids in ruminant diets, and they differ in the type and levels of fatty acids which they contribute to the diet. The sources are:

(1) forages,

(2) oils and oilseeds,

(3) fish oil,

(4) fat supplements.

\section{Forages}

Forages contribute to the supply of fatty acids in one of two ways. First, the rumen microorganisms ferment cellulose and hemicellulose in the forage to acetate and butyrate, which are the precursors for de novo synthesis of milk fat in the mammary gland, and second, forages contain low concentrations of oil (25-50 g oil $/ \mathrm{kg} \mathrm{DM}$ depending on forage type). Despite their low oil content, forages may account for $25-35 \%$ of total fatty acid intake in 
early lactation because they are usually eaten in large amounts. The fatty acids present in fresh grass are highly unsaturated with $60 \mathrm{~g} / 100 \mathrm{~g}$ oil as $18: 3$ and a further $13 \mathrm{~g} / 100 \mathrm{~g}$ as 18:2 (Christie, 1981). The extent to which these PUFA survive either ensiling or drying is unclear. There is some evidence that cows fed on either fresh grass or hay have higher levels of $n-3$ PUFA in the milk than cows fed on grass silage (Mpelimpasakes, 1981; Hebeisen et al. 1993). Maize silage is becoming an important forage crop in the UK, and although the oil extracted from the grain contains high levels of $18: 1$ and $18: 2$ (approximately 30 and $50 \mathrm{~g} / 100 \mathrm{~g}$ total fatty acids respectively) there is scant information on the fatty acid composition of maize silage.

\section{Oils and oilseeds}

Plant seeds store energy either as starch or in the form of oil. The fatty acid composition of seed oils varies widely and often one fatty acid predominates as a characteristic of a particular plant family (Fig. 1).

In recent years interest has focused on feeding diets containing either whole oilseeds or seed oils as a source of oleic (18:1), linoleic $(18: 2)$ and $\alpha$ - or $\gamma$-linolenic (18:3) acids. A number of workers have reported changes in the fatty acid composition of milk fat as a result of feeding various forms of rapeseed (Murphy et al. 1990, 1995a; Ashes et al. 1992; Emanuelson et al. 1992; Jahreis \& Richter, 1994), soyabeans (Dhiman et al. 1991; Socha et al. 1991; Chouinard et al. 1992; Murphy et al. 1995b), sunflowerseeds (Stegman et al. 1992), linseed (Ali et al. 1991; Khorasani et al. 1992) and evening primrose oil (Hermansen et al. 1995). In general, inclusion of these oils or oilseeds in the diet of

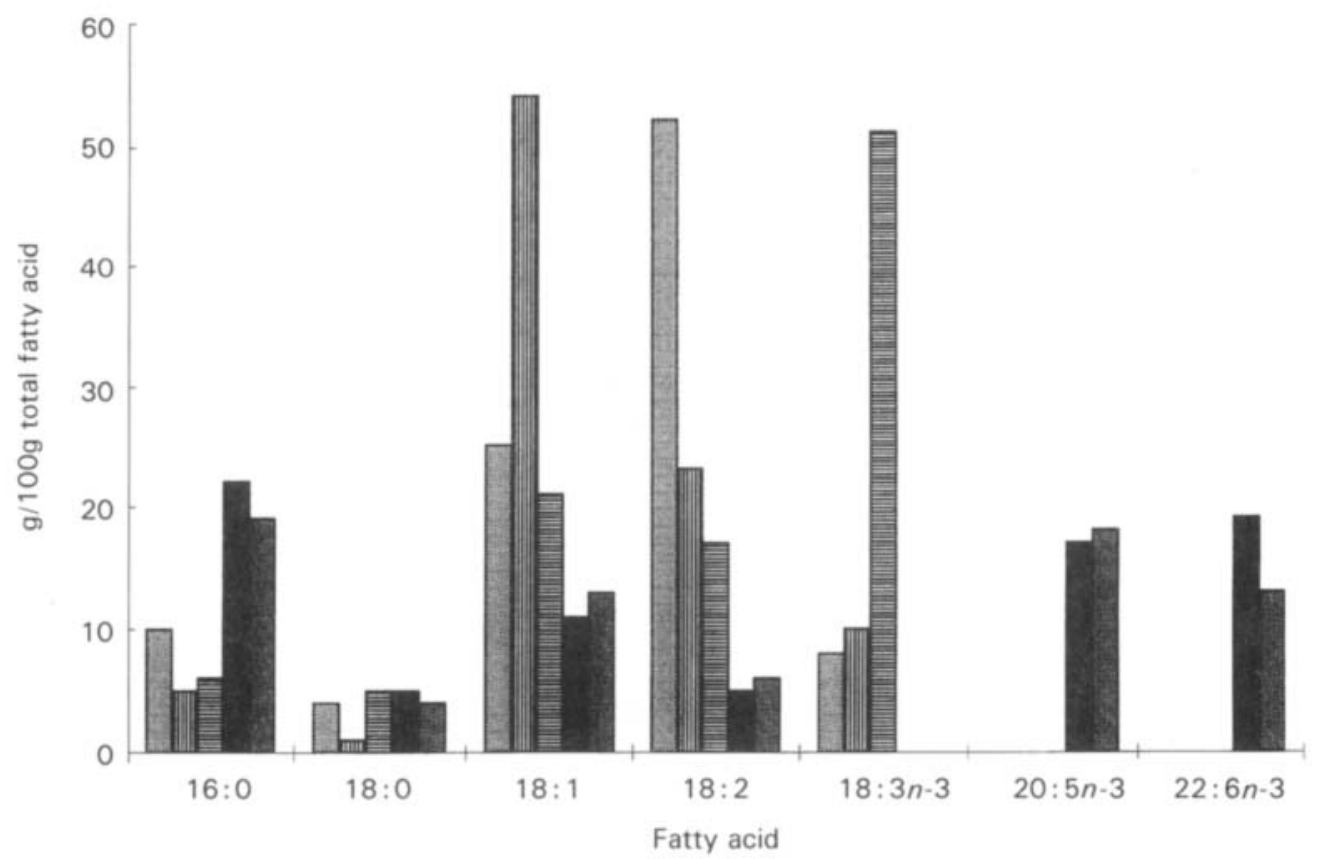

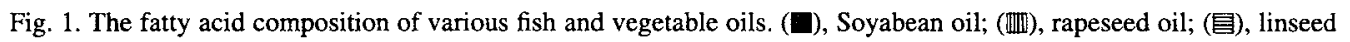

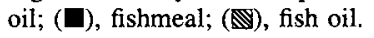


lactating dairy cows results in reductions in the levels of C4-C16 milk fatty acids and an increase in the levels of one or more of the long-chain fatty acids 18:0, 18:1, 18:2 or 18:3.

The form in which the oil is presented to the rumen can have an effect on the fatty acid composition of milk fat. The greater the degree of protection from hydrogenation in the rumen, for example when contained within the whole oilseed, the lower the level of $18: 1$ in the milk fat and the higher the levels of 18:0 and 18:2 when compared with the extracted oil (Steele et al. 1971).

Grain seeds are not usually regarded as a source of oil, but naked oats (Avena sativa var. nuda) contain $90-100 \mathrm{~g}$ oil $/ \mathrm{kg}$, almost twice as much as barley or wheat and $40-50 \mathrm{~g} /$ $100 \mathrm{~g}$ of the oil is in the form of PUFA (Morrison, 1977). Consequently some studies have investigated the effect of feeding naked oats on fatty acid composition of milk (Martin \& Thomas, 1988).

\section{Fish oils}

Plants, unlike animals, can synthesize de novo $\alpha$-linolenic acid $(18: 3 n-3)$, the parent compound of the $n-3$ series of essential fatty acids. Marine plants, in particular, have the ability to elongate and desaturate the parent compound to yield $n-3$ PUFA with C20 and C22 chain lengths. It is the formation of these long-chain $n-3$ PUFA by marine algae and their efficient transfer through the food chain to fish, that accounts for the abundance of C20 and C22 n-3 PUFA in marine fish oils.

There is currently some controversy concerning the extent to which $n-3$ PUFA in fish oils are transferred to milk fat. Efficiencies reported in the literature range from poor, following intravenous infusion of cod-liver oil (Storry et al. 1969) to good (35-40\% transfer) following post-ruminal infusion of menhaden oil (Hagmeister et al. 1988). Grummer (1991) suggests that this discrepancy may be explained because Storry et al. (1969) administered non-physiological forms of fish oil triacylglycerol directly into the circulatory system instead of incorporation of the fatty acids into intestinally synthesized lipoproteins which would occur following post-ruminal infusion. However, in a study where dairy cows were fed on diets containing cod-liver oil, there was no 20:5 or 22:6 transferred to milk fat although the levels of 20:0,20:1 and 22:0 increased (Brumby et al. 1972). Some authors suggest that the PUFA in fish oil may not be hydrogenated in the rumen. In vitro studies where a fish oil-casein mixture $(1: 1, \mathrm{w} / \mathrm{w})$ was incubated with rumen contents from sheep for $24 \mathrm{~h}$, showed a reduction in 18:1 (cis and trans), but no change in 20:5 and 22:6 levels (Ashes et al. 1992).

\section{Fat supplements}

Fat supplements tend to be given as energy supplements and have been developed to minimize any adverse effect on fibre digestion or microbial activity in the rumen. Consequently, the fat supplements in widespread use in the UK contain predominately saturated fatty acids based on palm fatty acids or mixtures of partially hydrogenated waste fats from the human food industry. The use of tallows in UK ruminant feeds is currently limited because of the risk of transmission of factors linked to bovine spongiform encephalopathy (BSE) in cattle. 


\section{THE EFFECT OF THE RUMINANT DIGESTIVE TRACT ON THE SUPPLY OF FATTY ACIDS}

Although the composition of cows' milk is influenced by the type and level of fat in the diet, the relationship is modified by the effect of the digestive tract. Nowhere is this effect more profound than in the rumen where extensive metabolism of lipid occurs before digestion and absorption in the small intestine. A complex population of micro-organisms within the rumen secretes enzymes which hydrolyse the dietary lipid to free fatty acids and glycerol. The glycerol is fermented to volatile or short-chain fatty acids which are absorbed through the wall of the rumen and/or true stomach. They may eventually contribute to the pool of acetate and butyrate used for de novo synthesis of fatty acids in the mammary gland.

The short-chain saturated free fatty acids, released as a result of microbial lipase activity are absorbed through the walls of the rumen or abomasum into the bloodstream. The medium- and longer-chain saturated fatty acids pass into the small intestine. The majority of unsaturated fatty acids are extensively hydrogenated in the rumen (Ward et al. 1964) by enzymes within the rumen micro-organisms. Hydrogenation is often accompanied by positional isomerization of the double bond under attack, changing it from the cis to trans position (Fig. 2). It is for this reason that ruminant products (meat and milk) are significant sources of trans fatty acids in the human diet.

Lipids, specifically those containing high levels of PUFA, have an adverse effect on rumen microflora and fibre digestion (Kowalczyk et al. 1977), and at high levels can reduce yields of milk and milk constituents. In addition, de novo milk fat synthesis can be depressed by high levels of trans 18:1 derived either from the diet or hydrogenation of unsaturated fatty acids in the rumen (Wonsil et al. 1994). Very long PUFA are also known to interfere with milk fat production by reducing the uptake of medium- and long-chain fatty acids (Brumby et al. 1972; Storry et al. 1974).

The rumen micro-organisms incorporate some of the hydrogenated fatty acids into microbial lipid, which therefore contains a high proportion of saturated, as well as small

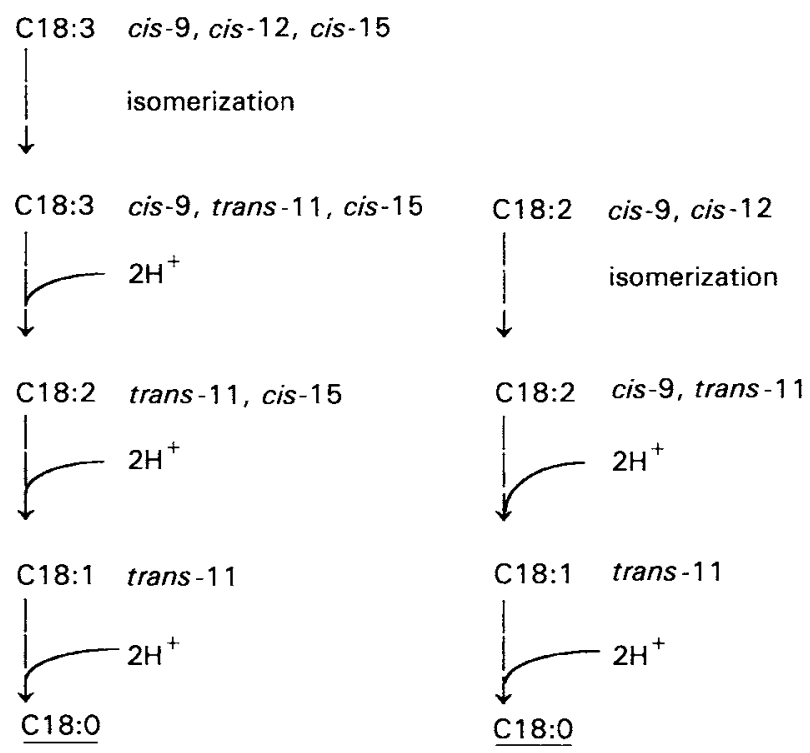

Fig. 2. The major metabolic pathways for the biohydrogenation of the fatty acids $18: 2$ and 18:3. 
Table 3. Lipid and fatty acid content of rumen bacteria

\begin{tabular}{lr}
\hline \hline & \\
\hline Lipid/fatty acid & $50-90$ \\
Total lipid (g/kg bacterial dry wt) & \\
Fatty acids (g/100 g total fatty acid) & 2 \\
$14: 0$ & 2 \\
$14: 0(\mathrm{br})$ & 4 \\
$15: 0$ & 10 \\
$15: 0(\mathrm{br})$ & 35 \\
$16: 0$ & 32 \\
$18: 0$ & 4 \\
$18: 1$ & 4 \\
$18: 2+18: 3$ & \\
\hline
\end{tabular}

br, branched.

amounts of branched and odd-chain-length fatty acids (Table 3). Rumen bacteria account for $10-15 \%$ of the lipid entering the small intestine.

On leaving the rumen, microbial lipid in the particulate phase passes into the acid environment of the abomasum where enzymic action releases the lipid fraction for subsequent digestion in the small intestine. The dietary lipid, which is mostly in the form of free fatty acids, is unaffected by the processes in the abomasum. In the small intestine, the digesta is mixed with pancreatic lipase $(E C$ 3.1.1.3) to break down any remaining triacylglycerols, and bile acids emulsify the fatty acids to facilitate the formation of micelles. These migrate to the brush-border membrane, where the fatty acids diffuse across the membrane wall and enter the lumen of the epithelial cells. On absorption, the free fatty acids are recombined with glycerol to form triacylglycerols, and incorporated into two types of lipoproteins, namely chylomicrons and VLDL, for transport around the body. These lipoproteins are extruded from the cells, enter the intestinal lymphatic system and finally pass into the blood. A proportion of the long-chain fatty acids may be absorbed directly into the portal vein.

\section{RECENT STUDIES TO MANIPULATE THE FATTY ACID COMPOSITION OF MILK FAT}

The objective of recent work at ADAS Bridgets Research Centre has been to build on and extend the scope of earlier work. This has involved the use of high-genetic-merit, highyielding cows in early to mid lactation fed to appetite on complete diets based on grass silage.

In the first of two experiments at the Centre, ninety-six cows in early lactation were fed on a control diet containing 0.6 or $0.9 \mathrm{~kg} \mathrm{DM} / \mathrm{d}$ of Megalac (Ca soap of palm fatty acid distillate; Volac Ltd, Royston, Herts.), or 4.9 or $7.9 \mathrm{~kg} \mathrm{DM} / \mathrm{d}$ of naked oats (NO), 2.3 or $3.7 \mathrm{~kg} \mathrm{DM} / \mathrm{d}$ of full-fat soyabeans (FFS) or 2.7 or $4.2 \mathrm{~kg} \mathrm{DM} / \mathrm{d}$ of partially oil-extracted rapeseed (PER) for 16 weeks. These feeding levels were similar to those previously reported of $7.3 \mathrm{~kg}$ DM of naked oats (Martin \& Thomas, 1988), $2.8 \mathrm{~kg}$ DM of FFS (Murphy et al. $1995 \mathrm{~b}$ ) and $1.5 \mathrm{~kg} \mathrm{DM}$ of full fat rapeseed (FFR) at grass (Murphy et al. 1995b) and $1.4 \mathrm{~kg} \mathrm{DM}$ of FFR with grass silage (Murphy et al. 1995a). In common with these studies, there were significant effects on the levels of long-chain saturated (16:0 and 18:0) and unsaturated fatty acids $(18: 1,18: 2$ and 18:3) associated with the test oils (Mansbridge \& Blake, 1995). Inclusion of NO, FFS and PER in the diet reduced the levels of 16:0 in the milk fat by $31 \%$. In relation to the control, diets containing PER reduced the level of 16:0 


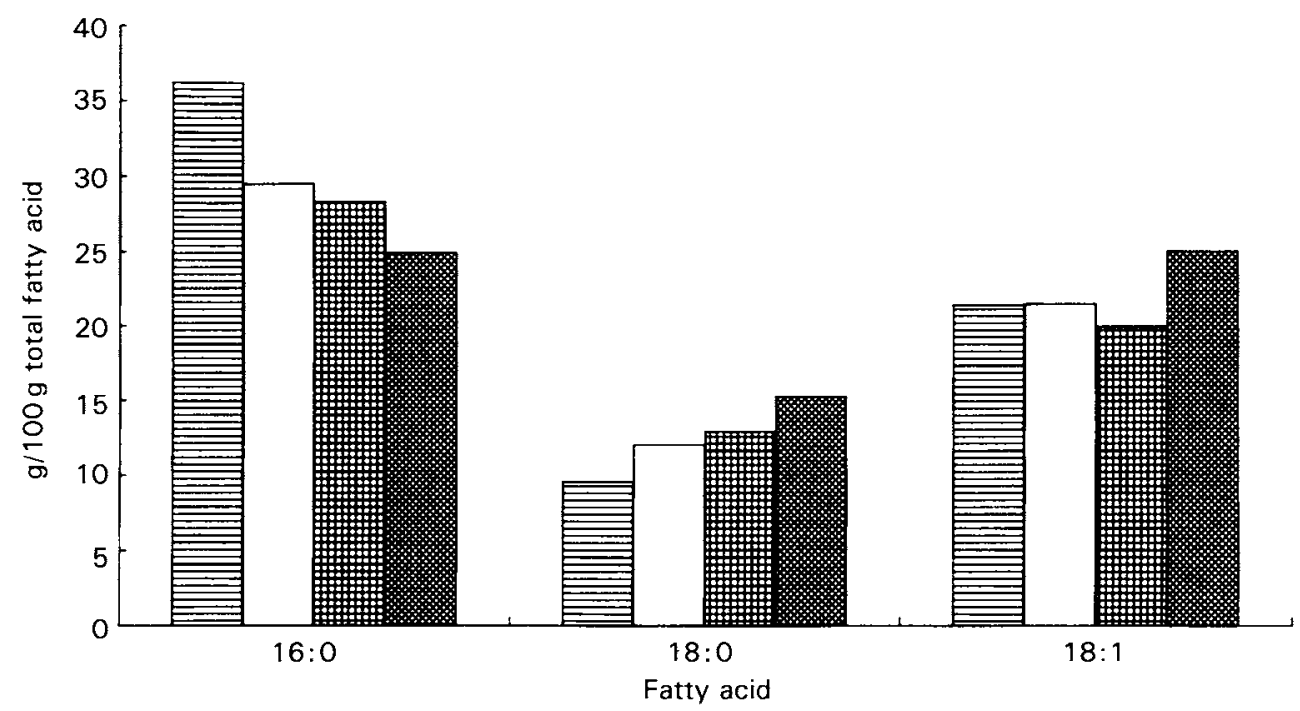

Fig. 3. The effect of dietary oil source on the concentrations of the fatty acids $16: 0,18: 0$ and $18: 1$ in bovine milk. Cows were fed on diets containing: (互), Megalac (a calcium soap of palm fatty acid distillate; control); ( $\square$ ), naked oats; (需), full-fat soyabeans or ( $\mathbf{W})$, partially oil-extracted rapeseed for 16 weeks.

and increased 18:0. The level of 18:3 in the milk fat was increased in both the FFS and PER diets (Figs. 3 and 4). Although NO modified milk fatty acid composition relative to the control, the changes in the long-chain saturated and unsaturated fatty acids were small in comparison with those achieved with FFS and PER. This was consistent with a marked depression in milk fat content on the NO diets (mean milk fat content $36.6 \mathrm{~g} / \mathrm{l}$ ) compared

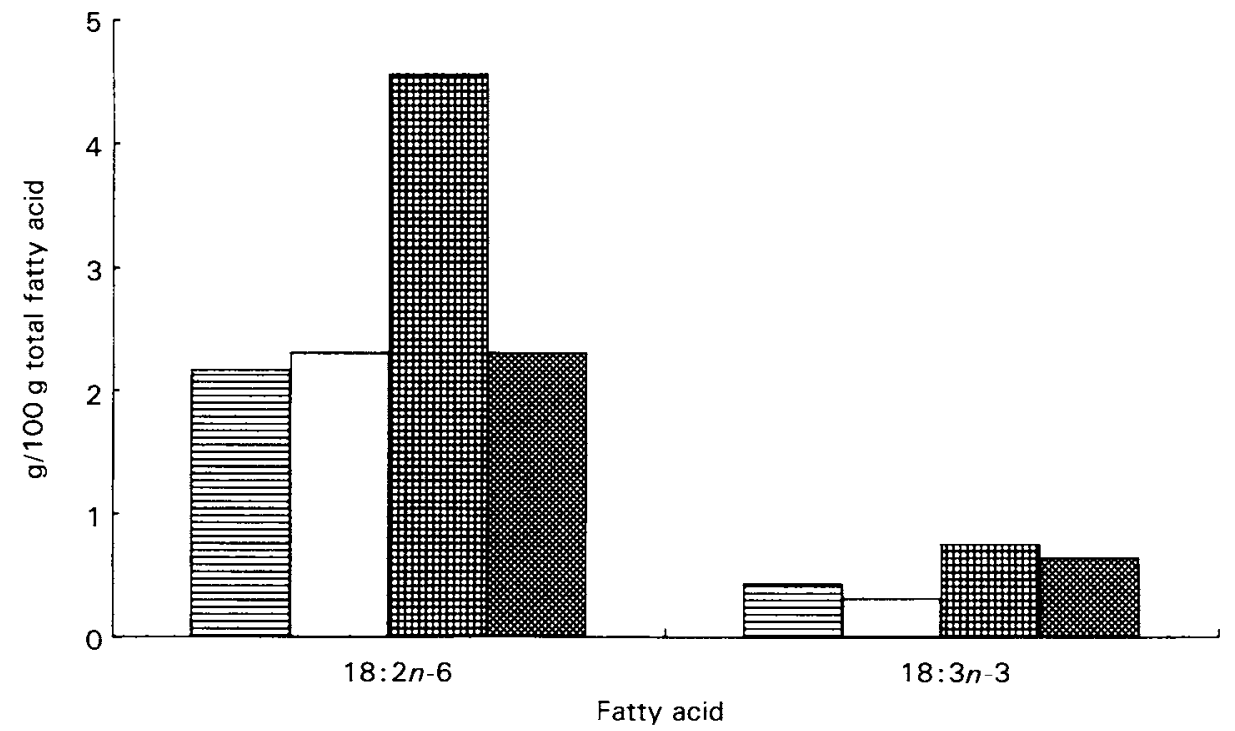

Fig. 4. The effect of dietary oil source on the concentrations of the fatty acids $18: 2$ and $18: 3$ in bovine milk. Cows were fed on diets containing: (冒), Megalac (a calcium soap of palm fatty acid distillate; control); ( $\square$ ), naked oats; (㭗), fullfat soyabeans or $(\square)$, partially oil-extracted rapeseed for 16 weeks. 


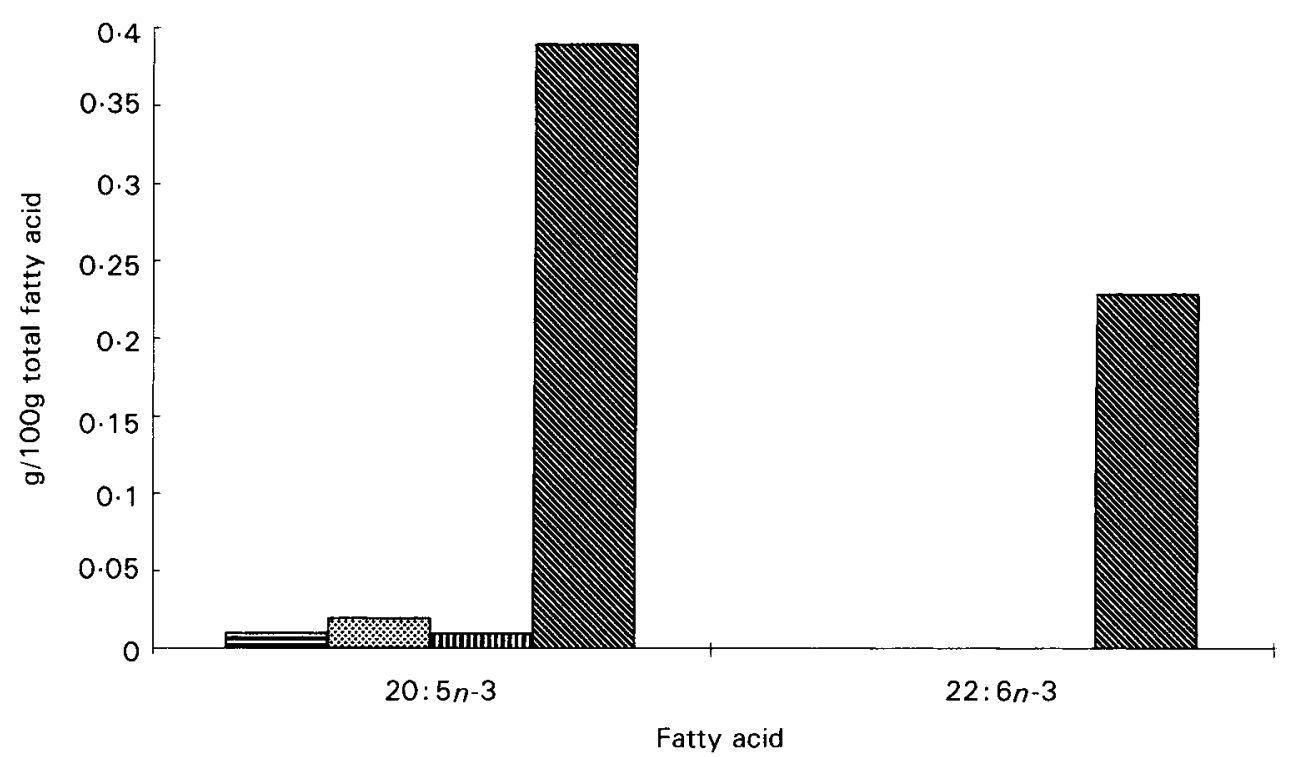

Fig. 5. The effect of dietary oil source on the concentrations of very-long-chain $n-3$ polyunsaturated fatty acids in bovine milk. Cows were fed on diets containing: (娄), Megalac (a calcium soap of palm fatty acid distillate; control); $(\square)$, soyabeans; (皿), rapeseed or $(\mathbb{N})$, fish oil.

with diets C, FFS and PER (mean milk fat contents $42.5,39.7$ and $39.8 \mathrm{~g} / \mathrm{l}$ respectively). It is interesting to note that the calculated efficiencies of capture of dietary C18 fatty acids $(18: 0,18: 1,18: 2$ and $18: 3)$ in milk fat were $0.84,0.69,0.71$ and $0.68 ; 0.93,0.53,0.47$ and 0.68 for diets containing C, NO, FFS and PER at the low and high levels of inclusion respectively.

A second experiment, only recently completed at the Centre, was designed to investigate the extent to which very-long-chain $n$ - 3 PUFA from fish oil and/or fish meal are transferred to milk fat. The concentrations in milk of 20:5 and 22:6 were significantly $(P<0.001)$ higher in a fish-oil treatment compared with a control diet containing Megalac (Fig. 5). Preliminary calculations suggest that the transfer efficiencies of dietary 20:5 and $22: 6$ to milk fat were 0.07 and 0.04 respectively.

\section{FUTURE WORK}

There has been considerable work undertaken in recent years to change milk fatty acid composition in ways which can be regarded as beneficial in terms of product quality and consumer perception, but there is still some way to go. It is evident that the mechanisms involved in the breakdown of dietary fat within the rumen and small intestine, the metabolism of fats within the animal and the synthesis and assimilation of milk fat within the mammary gland are complex and powerful. The modest efficiencies with which fatty acids regarded as important in human nutrition have been transferred from the diet to milk fat, raise important questions regarding the dietary sources investigated to date. There is clearly a need to identify or develop new raw materials which facilitate an improvement in the supply of desired fatty acids to, and uptake by, the mammary gland. In this context the role of fish oils as the principal source of very-long-chain $n$ - 3 fatty acids in dairy-cow diets raises important questions regarding the sustainability of this approach, particularly if 
transfer efficiencies to milk fat cannot be improved. In recognition of this the Ministry of Agriculture, Fisheries and Food has recently commissioned a review of alternative sources of the $n-3$ series of very-long-chain fatty acids.

Product quality is an important consumer issue and changes in fatty acid composition must be achieved against a background of increasing demand for cleaner, more hygienic milk with an enhanced shelf life. Work has recently started at ADAS Bridgets to investigate the effect of added dietary vitamin $\mathrm{E}$ on milk hygiene and shelf life.

The UK dairy industry is poised at a turning point in its development. The demise of the Milk Marketing Board, preceded by the arrival of the European Single Market, has encouraged a far closer relationship between many milk producers and milk buyers and led to an industry more attuned to the needs of the consumer. Competing retail outlets will continue to develop new and novel milks and milk products, and manipulating the fatty acid composition of milk fat provides exciting ways of developing these products.

The work carried out at the ADAS Bridgets Dairy Research Centre was partly funded by the European Community and by the UK Ministry of Agriculture, Fisheries and Food.

\section{REFERENCES}

Ali, T., Kurihara, M. \& Ishida, S. (1991). Increase in alpha-linolenic acid in milk fat by feeding the calcium soap of fatty acids prepared from linseed oil. Animal Feed Science and Technology 62, 58-62.

Ashes, J. R., St Vincent Welch, P., Gulati, S. K., Scott, T. W., Brown, G. H. \& Blakeley, S. (1992). Manipulation of the fatty acid composition of milk by feeding protected canola seed. Journal of Dairy Science 75, 10901096.

Ashes, J. R., Siebert, B. D., Gulati, S. K., Cuthbertson, A. Z. \& Scott, T. W. (1992). Incorporation of $n-3$ fatty acids of fish oil in tissue and serum lipids of ruminants. Lipids 27, 629-631.

Bickerstaffe, R. \& Annison, E. F. (1968). The desaturation of stearic acid by mammary-gland tissue of the lactating goat and sow. Biochemical Journal 107, 27p.

British Nutrition Foundation (1992). Unsaturated Fatty Acids. Report of the British Nutrition Foundation's Task Force. London: Chapman and Hall.

Brumby, P. E., Storry, J. E. \& Sutton, J. D. (1972). Metabolism of cod-liver oil in relation to milk fat secretion. Journal of Dairy Science 39, 167-182.

Chouinard, P. Y., Girard, V. \& Brisson, G. J. (1992). Fatty acid composition of cow's milk as influenced by feeding soybeans extruded at different temperatures. Journal of Dairy Science 75, Suppl. 1, 277.

Christie, W. W. (1981). Lipid Metabolism in Ruminant Animals. Oxford: Pergamon Press.

Department of Health (1994). Nutritional Aspects of Cardiovascular Disease. Report on Health and Social Subjects no. 46. London: H. M. Stationery Office.

Dhiman, T. R., van Zanten, K. \& Satter, L. D. (1991). Source of dietary fat and its effect on milk fatty acid composition. Journal of Dairy Science 74, Suppl. 1, 249.

Dryden, F. D., Marchello, J. A., Adams, G. H. \& Hale, W. H. J. (1971). Bovine serum lipids. II. Lipoprotein quantitative and qualitative composition as influenced by added animal fat diets. Joumal of Animal Science 32, 1016-1029.

Duncan, W. R. \& Garton, G. A. (1963). Plasma lipids of the cow during pregnancy and lactation. Biochemical Journal 89, 414-419.

Emanuelson, M., Ahlin, K. \& Wiktorsson, H. (1992). Long-term feeding of rapeseed meal and full-fat rapeseed of double low cultivars to dairy cattle. Livestock Production Science 33, 199-214.

Grummer, R. R. (1991). Effect of feed on the composition of milk fat. Journal of Dairy Science 74, 3244-3257.

Hagmeister, H., Precht, D. \& Barth, C. A. (1988). Studies on transfer of omega-3 fatty acids into bovine milk fat. Milchwissenschaft 43, 153-158.

Hebeisen, D. F., Hoeflin, F., Reusch, H. P., Junker, E. \& Lauterburg, B. H. (1993). Increased concentrations of omega- 3 fatty acids in milk and platelet rich plasma of grass-fed cows. International Journal for Vitamin and Nutrition Research 63, 229-233.

Hermansen, J. E. (1995). Prediction of milk fatty acid profile in dairy cows fed various fats in relation to human nutrition and health. In Lipids in Animal Nutrition, Seminar of Lipid Forum, Danish Institute of Animal Science, Foulum, October 25-26, 1995, p. 3. Tjiele: Scandinavian Forum for Lipid Research and Technology.

Hermansen, J. E., Jonsbo, F., Anderson, J. O., Michaelsen, K. F. \& Weisbjerg, M. R. (1995). On the transfer of gamma-linolenic acid into milk fat and its possible elongation to arachidonic acid by cows. Milchwissenschaft 50, 3-6. 
Jahreis, G. \& Richter, G. H. (1994). The effect of feeding rapeseed on the fatty acid composition of milk lipids and on the concentration of metabolites and hormones in the serum of dairy cows. Journal of Animal Physiology and Animal Nutrition 72, 71-79.

Khorasani, E., Okine, E. \& Kennelly, J. J. (1992). Influence of whole flaxseed on performance of mid-lactation dairy cows. Journal of Dairy Science 75, Suppl. 1, 171.

Kowalczyk, J., Ørskov, E. R., Robinson, J. J. \& Stewart, C. S. (1977). Effect of fat supplementation on voluntary food intake and rumen metabolism in sheep. British Journal of Nutrition 37, 251-257.

Mansbridge, R. J. \& Blake, J. S. (1995). The effect of feeding different sources and levels of oil on the fatty acid composition of bovine milk. In Lipids in Animal Nutrition, Seminar of Lipid Forum, Danish Institute of Animal Science, Foulum, October 25-26, 1995, p. 20. Tjiele: Scandinavian Forum for Lipid Research and Technology.

Martin, P. A. \& Thomas, P. C. (1988). Dietary manipulation of the yield and composition of milk: effects of dietary inclusions of barley and oats in untreated or formaldehyde-treated forms on milk fatty acid composition. Journal of the Science of Food and Agriculture 43, 145-154.

Milk Marketing Board (1994). Dairy Facts and Figures. Thames Ditton: The Federation of United Kingdom Milk Marketing Boards.

Morrison, W. R. (1977). Cereal lipids. Proceedings of the Nutrition Society 36, 143-148.

Mpelimpasakes, N. G. (1981). Effect of various rations on fatty acid composition of bovine milk fat. Ellenike Kteniatrike 24, 81-93.

Murphy, J. J., Connolly, J. F. \& McNeil, G. P. (1995a). Effects on milk fat composition and cow performance of feeding concentrates containing full fat rapeseed and maize distillers grains on grass-silage based diets. Livestock Production Science 44, 1-11.

Murphy, J. J., Connolly, J. F. \& McNeil, G. P. (1995b). Effects on cow performance and milk fat composition of feeding full fat soyabeans and rapeseeds to dairy cows at pasture. Livestock Production Science 44, 13-25.

Murphy, J. J., McNeil, G. P., Connolly, J. F. \& Gleeson, P. A. (1990). Effect on cow performance and milk fat composition of including full fat soyabeans and rapeseeds in the concentrate mixture for lactating dairy cows. Journal of Dairy Research 57, 295-306.

Palmquist, D. L. \& Mattos, W. (1978). Turnover of lipoproteins and transfer to milk fat of dietary (1-carbon-14) linoleic acid in lactating cows. Journal of Dairy Science 61, 561-565.

Socha, M. T., Satter, L. D. \& Brotz, P. B. (1991). Effect of heat-processed whole soybeans on the fatty acid profile of milk. Journal of Dairy Science 74, Suppl, 1, 259.

Steele, W., Noble, R. C. \& Moore, J. H. (1971). The effects of 2 methods of incorporating soybean oil into the diet on milk yield and composition in the cow. Journal of Dairy Research 38, 49-56.

Stegman, G. A., Casper, D. P., Schingoethe, D. J. \& Baer, R. J. (1992). Lactational responses of dairy cows fed unsaturated dietary fat and receiving bovine somatotrophin. Journal of Dairy Science 75, 1936-1945.

Storry, J. E. (1981). The effect of dietary fat on milk composition. In Recent Advances in Animal Nutrition, pp. 3-33 [W. Haresign, editor]. London: Butterworths.

Storry, J. E., Brumby, P. E., Hall, A. J. \& Tuckley, B. (1974). Effects of free and protected forms of cod liver oil on milk fat secretion in the dairy cow. Journal of Dairy Science 57, 1046-1049.

Storry, J. E., Hall, A. J., Tuckley, B. \& Millard, D. (1969). The effects of intravenous infusions of cod-liver and soya-bean oils on the secretion of milk fat in the cow. British Journal of Nutrition 23, 173-180.

Ward, P. F. V., Scott, T. W. \& Dawson, R. M. C. (1964). The hydrogenation of unsaturated fatty acids in the bovine digestive tract. Biochemical Journal 92, 60-68.

Wonsil, B. J., Herbein, J. H. \& Watkins, B. A. (1994). Dietary and ruminally derived trans-18:1 fatty acids alter bovine milk lipids. Journal of Nutrition 124, 556-565. 